\title{
Surgical Training of Undergraduate Students at Mosul College of Medicine: A Preliminary Evaluation
}

\author{
Mahmood A Sulaiman Aljumaily*, Khalaf Alluaizy ${ }^{\star}$, Waleed Ghanim Ahmad**, \\ Abdulsalam Almasry* \\ *Department of Surgery, Collage of Medicine, University of Mosul , ** Department of Family and \\ Community Medicine, Collage of Medicine, University of Mosul , Mosul , Iraq \\ Correspondence: drwaleed1961@yahoo.com
}

(Ann Coll Med Mosul 2021; 43 (2):115-122).

Received: $5^{\text {th }}$ June 2021; Accepted: $31^{\text {th }}$ August 2021.

\begin{abstract}
Background: There is an idea that the level of medical college graduates is less than the expected. The improvement of medical training level for the undergraduates in medical schools need a re-evaluation and improvement for creation of new training programs including a better surgical training.

Objective: Is to evaluate the clinical surgical training of undergraduates at College of Medicine, University of Mosul.

Participants and methods: The study carried out at College of Medicine, University of Mosul during the year 2019. The study depends on questionnaire directed to 46 final year students who recently finished their clinical surgical training, 53 resident doctors graduated from the same college working among surgical wards, and 50 surgical department teachers and expert surgeons interested in medical education. The questionnaire asked about : does the student gain sufficient knowledge and clinical surgical skills during training, does the training provide safe doctor in work, does the training provide proper communication skills and ability to work properly in teams, and does the graduate able to gain the confidence of patients and other health workers. The participants score freely their answer in grade extend from 1-10, and asked to add any other notes up on surgical training of students including deleting or adding or any other suggestion.

Results: Knowledge gaining mean score by medical students, resident doctors, and expert surgeons was $6.9 \pm 1.45, \quad 6.68 \pm 1.82 \& 6.68 \pm 1.95$ respectively, while mean score for providing safe doctor to community was $6.04 \pm 1.39,6.52 \pm 1.40 \& 6.17 \pm 1.17$ respectively. On the other hand the mean score gaining regarding communication skills and ability to work in teams was $6.30 \pm 1.44,6.37 \pm 1.41 \& 6.59 \pm$ 1.13 respectively, while gaining the confidence of patients and other health workers mean score was $6.47 \pm$ $1.18,6.74 \pm 1.45$ and $6.66 \pm 0.99$ respectively. In all , there was no significant differences. The clinical surgical skills gaining mean score by medical students, resident doctors and expert surgeons was $6.26 \pm$ $1.61, \quad 4.92 \pm 1.70$, and $5.8 \pm 1.84$ respectively. Which reflect the presence of a significant differences between resident doctors in comparison to students and expert surgeons.

Conclusion: There is lower mean score in gaining clinical surgical skills of graduates and there is a need for more clinical training, improvement, development of clinical training, and a re-evaluation of clinical training to improve the quality of medical teaching to get competent graduates.
\end{abstract}

Keywords: surgical training, evaluation, undergraduate students, medical school, knowledge, clinical skills.

$$
\begin{aligned}
& \text { التدريب الجراحي لطلاب البكالوريوس في كلية طب الموصل: تقييم أولي } \\
& \text { محمود عبد سليمان الجميلي* ، خلف جدوع اللويزي* ، وليد غانم احمد الطائي }
\end{aligned}
$$

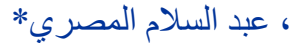

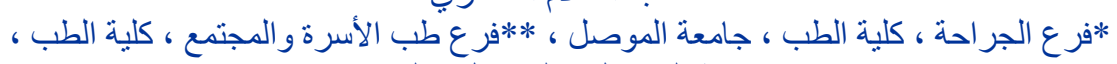

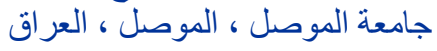

خلفية الدراسة : هناك فكرة بأن مستوى خريجي كلية الطب هو أقل من المتوقع .ان تحسين مستوى تدريب طلبة كليات الطب

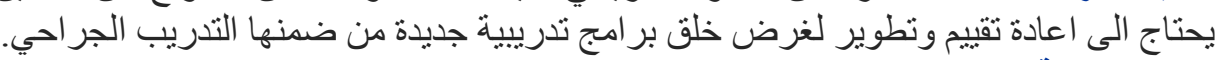

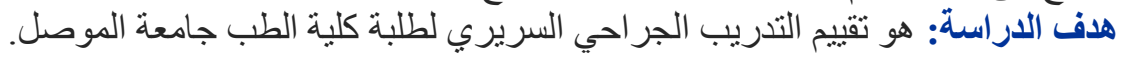




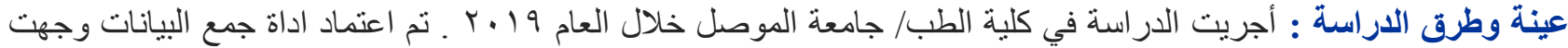

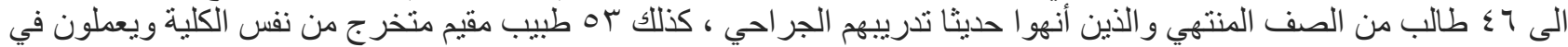

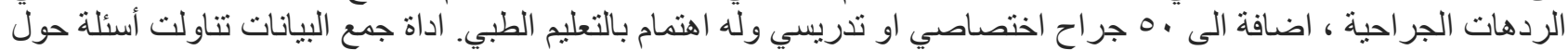

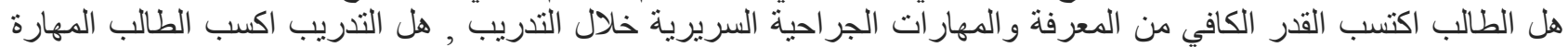

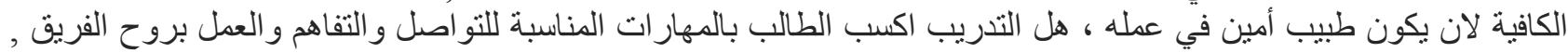

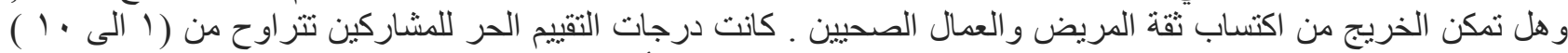

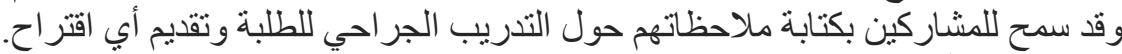

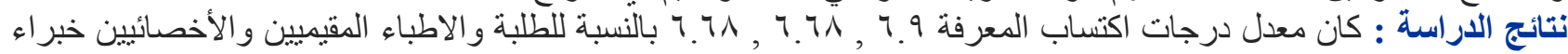

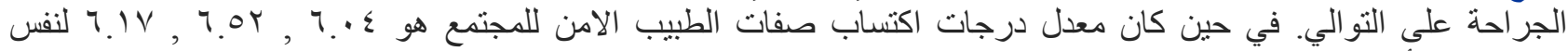

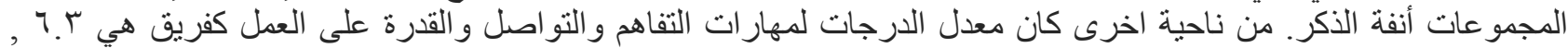

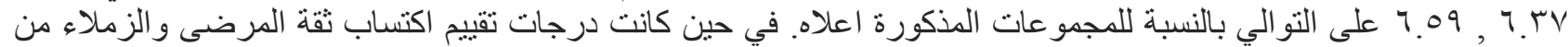

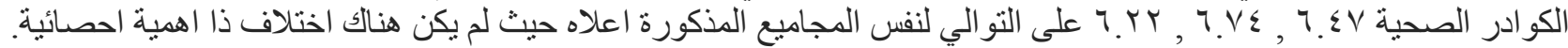

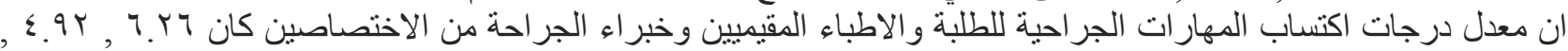

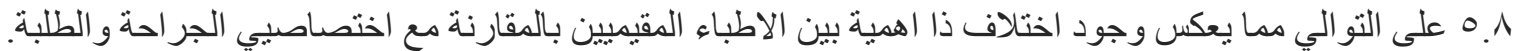

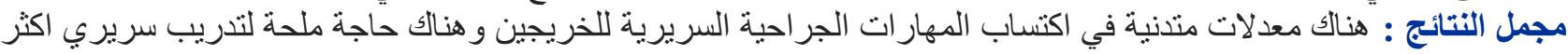

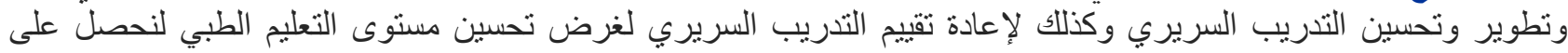
خريج كفوء. الكلمات المفتاحية : التدريب الجراحي ، تقييم ، الطلبة غير المتخرجين / كلية الطب ، المعرفة ، المهارات السريرية .

\section{INTRODUCTION}

Tr he training program in medical school should be directed to provide competent graduate that serve the needs of local community. There is a continuous need to determine the level of clinical training for medical students. There was wide satisfaction that the graduate not prepared well for daily tasks in hospitals and their surgical skill are below the acceptable level ${ }^{1,2}$. The aim of the undergraduate surgical training is to prepare trainees to enter the clinical practice in rapid safe way $^{3}$.

Surgical training of undergraduate medical students in basic clinical skills is an important part of their studies ${ }^{1}$. Surgical skills training is a hard job, it needs large number of efficient surgical teachers, enthusiastic student, scientific media of teaching and efficient programme of teaching and repeated evaluation and development ${ }^{4}$. Medical students, surgical training differs in the various countries. Self-evaluation of surgical training by medical students can be applied ${ }^{1}$.

Clinical training including surgical training in Iraq suffered from regression caused by many factors. There are few scientific reports on clinical training in our community ${ }^{5}$. The aim of this study is to evaluate the level of clinical surgical training carried out at College of Medicine, University of Mosul.

\section{PARTICIPANTS AND METHODS}

The study carried out at the College of Medicine, University of Mosul at period between April - November 2019. The study approved by research ethics committee at College of Medicine. College of Medicine, University of Mosul is the oldest college in North of Iraq, it is established at 1959 . The teaching in the College is six years, the first 3 years mainly basic and fourth to sixth years are clinical teaching. Mosul is the second city in North of Iraq, it was occupied by ISIS at 10 June 2014 , and subjected to wide destruction by occupation and military activities until its complete liberation at 8 December 2017.

The study depends on questionnaire designed to ask the participant on , is the graduate gain sufficient knowledge in surgery?, is the graduate gain sufficient surgical skill during their training ?, is the training provide safe doctor in work?, is the graduate gain sufficient skill of communications and ability to work in teams ?, and is the graduate gain the confidence of patients and other health workers?. Before the questionnaire was administered, its purpose was explained to participants and their individual permission secured. Names of the participants were not recorded. The participant asked to answer in grade, the grade scale extend form 0-10 and the participant mark the grade freely. The questionaries' also asked to comment on any suggestion to correct program of surgical training by deleting some part of program, or adding more 
clinical training, or to improve and develop the clinical training and adding more subjects.

The Questionnaire given to three groups, the first group is the $6^{\text {th }}$ year students who complete their surgical training, 70 questionnaire forms send to students, 46 complete the questionnaire (response rate is $66 \%$ ). The second group was the recently graduated doctors who are graduated from Mosul College of Medicine and are working as surgical ward resident doctors , 70 questionnaire forms sent to resident doctors, only 53 resident doctor complete the questionaire (with response rate of $75 \%$ ). The third group was the expert surgeons and surgical teachers involved in surgical teaching and training, who are working in surgical wards and who are sharing in undergraduate and postgraduate clinical training . Seventy questionnaire forms sent to expert surgeons, only 50 surgeons complete the questionnaire ( with a response rate of $71.4 \%$ ). The data collected and analyzed. Statistical analysis carried out by Excel for Office 365, the mean and standard deviation calculated. Data were imported into SPSS 24 (Version 24.0. Armonk, NY: IBM Corp.) for inferential analysis. Multivariant ANOVA used in comparing the groups, and Duncan test used also.

\section{RESULTS}

The final year medical school students share in this study were 46 ( 27 females and 19 males), their mean age was $23.97 \pm 0.77$. The resident doctors in surgical wards who had been graduated from the same college were 53 ( 28 females and 25 males), their mean age was $26.59 \pm 1.84$. The expert surgeons and surgical teachers who share in this study were 50 ( 3 females and 47males), and their mean age was $47.12 \pm 9.2$ (table 1 ).

The mean knowledge gaining score by students is $6.9 \pm 1.45$, by resident doctors is $6.68 \pm 1.82$, and by expert surgeons is $6.68 \pm 1.95$ (table 1 ). Using paired t-test, ANOVA and Duncan test, there was no significant differences (table 2). .The mean surgical skills gaining score by students is $6.26 \pm$ 1.61 , by resident doctors is $4.92 \pm 1.70$, and by expert surgeons is $5.8 \pm 1.8$. Using paired t-test, ANOVA and Duncan test, there was statistically significant differences between resident doctors and students and expert surgeons (table 3).Providing safe doctor to community mean score by students is $6.04 \pm 1.39$, by resident doctors is $6.52 \pm 1.40$, and by expert surgeons is $6.17 \pm$ 1.17 . Again by using paired t-test, ANOVA and Duncan test, there was no significant differences (table 4). Skills of communication and ability to work in teams mean score by students is $6.30 \pm$ 1.44 , by resident doctors is $6.37 \pm 1.41$, and by expert surgeon is $6.59 \pm 1.13$. By using paired ttest, ANOVA and Duncan test, there was statistically non- significant differences (table 5). Gaining the confidence of patients and other health workers mean score by students is $6.47 \pm 1.1$, by resident doctors is $6.74 \pm 1.45$, and by expert surgeons is $6.66 \pm 0.99$. By using paired t-test, ANOVA and Duncan test, there was no statistically significant differences (table 6).

Sixteen of students, 14 of resident doctors, and 6 of expert surgeons suggest to remove some of details and rare diseases. The suggestion of adding more clinical training and more training in emergency accepted by 16 students, 32 resident doctors and 20 expert surgeons. The suggestion of improvement and development of surgical training accepted by 11 students, 26 resident doctors and 22 expert surgeons.

Table-1- The demographic characteristics and mean score of surgical training by participants.

\begin{tabular}{|c|c|c|c|c|}
\hline \multicolumn{2}{|c|}{$\begin{array}{l}\text { Demographic and } \\
\text { surgical training } \\
\text { parameter }\end{array}$} & $\begin{array}{l}\text { Medical } \\
\text { students }\end{array}$ & $\begin{array}{l}\text { Residen } \\
\text { t doctors }\end{array}$ & $\begin{array}{c}\text { Expert } \\
\text { surgeons }\end{array}$ \\
\hline \multicolumn{2}{|c|}{$\begin{array}{l}\text { Number of } \\
\text { participants }\end{array}$} & 46 & 53 & 50 \\
\hline \multirow{2}{*}{ Gender } & Male & 19 & 25 & 42 \\
\hline & Female & 27 & 26 & 3 \\
\hline \multicolumn{2}{|c|}{ Mean age } & $\begin{array}{l}23.97 \\
\pm 0.77\end{array}$ & $\begin{array}{l}26.59 \\
\pm 1.84\end{array}$ & $\begin{array}{c}47.12 \\
\pm 9.2\end{array}$ \\
\hline \multicolumn{2}{|c|}{$\begin{array}{l}\text { Knowledge } \\
\text { gaining mean } \\
\text { score }\end{array}$} & $\begin{array}{c}6.9 \\
\pm 1.45\end{array}$ & $\begin{array}{c}6.68 \pm \\
1.82\end{array}$ & $\begin{array}{c}6.68 \\
\pm 1.95\end{array}$ \\
\hline \multicolumn{2}{|c|}{$\begin{array}{l}\text { Surgical skills } \\
\text { gaining mean } \\
\text { score }\end{array}$} & $\begin{array}{c}6.26 \\
\pm 1.61\end{array}$ & $\begin{array}{c}4.92 \pm \\
1.70\end{array}$ & $\begin{array}{l}5.8 \pm \\
1.84\end{array}$ \\
\hline \multicolumn{2}{|c|}{$\begin{array}{l}\text { providing safe } \\
\text { doctor mean } \\
\text { score }\end{array}$} & $\begin{array}{c}6.04 \\
\pm 1.39\end{array}$ & $\begin{array}{c}6.52 \pm \\
1.40\end{array}$ & $\begin{array}{c}6.17 \\
\pm 1.17\end{array}$ \\
\hline \multicolumn{2}{|c|}{$\begin{array}{l}\text { communications } \\
\text { skills and ability } \\
\text { to work in teams } \\
\text { mean score }\end{array}$} & $\begin{array}{c}6.30 \\
\pm 1.44\end{array}$ & $\begin{array}{c}6.37 \pm \\
1.41\end{array}$ & $\begin{array}{c}6.59 \\
\pm 1.13\end{array}$ \\
\hline \multicolumn{2}{|c|}{$\begin{array}{l}\text { gaining the } \\
\text { confidence of } \\
\text { patients and other } \\
\text { health workers } \\
\text { mean score }\end{array}$} & $\begin{array}{c}6.47 \\
\pm 1.18\end{array}$ & $\begin{array}{c}6.74 \\
\pm 1.45\end{array}$ & $\begin{array}{c}6.66 \\
\pm 0.99\end{array}$ \\
\hline
\end{tabular}


Table -2. Paired t-test, ANOVA and Duncan test for knowledge gaining score assessment

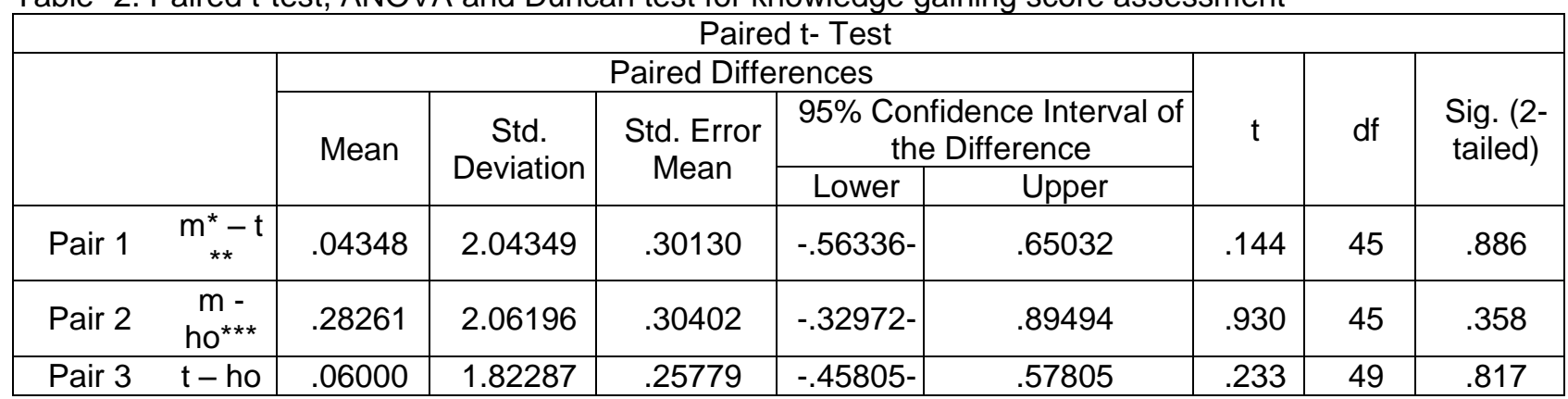

* Medical students

** expert surgeons

*** house officer doctors

\begin{tabular}{|l|l|l|l|l|l|}
\hline \multicolumn{9}{|c|}{ ANOVA } \\
\hline & Sum of Squares & Df & Mean Square & F & Sig. \\
\hline Between Groups & 1.930 & 2 & .965 & .489 & .614 \\
Within Groups & 288.311 & 146 & 1.975 & & \\
Total & 290.242 & 148 & & & \\
\hline
\end{tabular}

\begin{tabular}{|ll|l|l|}
\hline \multicolumn{2}{|c|}{ Duncan test } \\
\hline & \multirow{2}{*}{ VAR00003 } & \multirow{2}{*}{$\mathrm{N}$} & Subset for alpha $=0.05$ \\
\cline { 3 - 4 } & & & 1 \\
\hline \multirow{2}{*}{ Duncan $^{\mathrm{a}, \mathrm{b}}$} & $\mathrm{Ho}$ & 53 & 6.6604 \\
& $\mathrm{~T}$ & 50 & 6.7400 \\
& $\mathrm{M}$ & 46 & 6.9348 \\
& Sig. & & .364 \\
\hline
\end{tabular}

Means for groups in homogeneous subsets are displayed.

a. Uses Harmonic Mean Sample Size $=49.499$.

b. The group sizes are unequal. The harmonic mean of the group sizes is used. Type I error levels are not guaranteed.

Table -3. Paired t-test, ANOVA and Duncan test of assessment results for surgical skills gaining score.

\begin{tabular}{|c|c|c|c|c|c|c|c|c|}
\hline \multicolumn{9}{|c|}{ Paired Samples Test } \\
\hline & \multicolumn{5}{|c|}{ Paired Differences } & \multirow{3}{*}{$\mathrm{T}$} & \multirow{3}{*}{ df } & \multirow{3}{*}{$\begin{array}{l}\text { Sig. }(2 \\
\text { tailed) }\end{array}$} \\
\hline & \multirow[t]{2}{*}{ Mean } & \multirow{2}{*}{$\begin{array}{c}\text { Std. } \\
\text { Deviation }\end{array}$} & \multirow{2}{*}{$\begin{array}{l}\text { Std. Error } \\
\text { Mean }\end{array}$} & \multicolumn{2}{|c|}{$\begin{array}{l}95 \% \text { Confidence Interval } \\
\text { of the Difference }\end{array}$} & & & \\
\hline & & & & Lower & Upper & & & \\
\hline Pair $1 \mathrm{~m}-\mathrm{t}$ & .36957 & 2.31285 & .34101 & $-.31727-$ & 1.05640 & 1.084 & 45 & .284 \\
\hline Pair $2 \mathrm{t}-$ ho & .96000 & 2.79913 & .39586 & .16450 & 1.75550 & 2.425 & 49 & .019 \\
\hline Pair 3 ho $-m$ & $-1.32609-$ & 2.55651 & .37694 & $-2.08528-$ & $-.56690-$ & $-3.518-$ & 45 & .001 \\
\hline
\end{tabular}

\begin{tabular}{|c|c|c|c|c|c|}
\hline \multicolumn{6}{|c|}{ ANOVA } \\
\hline & Sum of Squares & Df & Mean Square & $\mathrm{F}$ & Sig. \\
\hline Between Groups & 47.265 & 2 & 23.632 & 8.363 & .000 \\
\hline Within Groups & 412.588 & 146 & 2.826 & & \\
\hline Total & 459.852 & 148 & & & \\
\hline
\end{tabular}




\begin{tabular}{|c|c|c|c|c|}
\hline \multicolumn{5}{|c|}{ Duncan test } \\
\hline & \multirow{2}{*}{ VAR00003 } & \multirow{2}{*}{$\mathrm{N}$} & \multicolumn{2}{|c|}{ Subset for alpha $=0.05$} \\
\hline & & & 1 & 2 \\
\hline \multirow{4}{*}{ Duncan $^{\mathrm{a}, \mathrm{b}}$} & \multirow{4}{*}{$\begin{array}{c}\mathrm{H} \\
\mathrm{T} \\
\mathrm{M} \\
\mathrm{Si}\end{array}$} & 53 & 4.9245 & \\
\hline & & 50 & & 5.8600 \\
\hline & & 46 & & 6.2609 \\
\hline & & & 1.000 & .237 \\
\hline
\end{tabular}

Means for groups in homogeneous subsets are displayed.

a. Uses Harmonic Mean Sample Size $=49.499$.

b. The group sizes are unequal. The harmonic mean of the group sizes is used. Type I error levels are not guaranteed.

Table -4. Paired t-test, ANOVA and Duncan test for assessment results regarding whether the training provide safe doctor in work.

\begin{tabular}{|c|c|c|c|c|c|c|c|c|}
\hline \multicolumn{9}{|c|}{ Paired Samples Test } \\
\hline & \multicolumn{5}{|c|}{ Paired Differences } & \multirow{3}{*}{$\mathrm{t}$} & \multirow{3}{*}{$\mathrm{df}$} & \multirow{3}{*}{$\begin{array}{l}\text { Sig. }(2 \\
\text { tailed })\end{array}$} \\
\hline & \multirow{2}{*}{ Mean } & \multirow{2}{*}{$\begin{array}{c}\text { Std. } \\
\text { Deviation }\end{array}$} & \multirow{2}{*}{$\begin{array}{l}\text { Std. Error } \\
\text { Mean }\end{array}$} & \multicolumn{2}{|c|}{$\begin{array}{l}95 \% \text { Confidence Interval } \\
\text { of the Difference }\end{array}$} & & & \\
\hline & & & & Lower & Upper & & & \\
\hline Pair $1 \mathrm{~m}-\mathrm{t}$ & .08696 & 1.95307 & .28796 & $-.49303-$ & .66695 & .302 & 45 & .764 \\
\hline Pair $2 \mathrm{t}-$ ho & $-.30000-$ & 1.78714 & .25274 & $-80790-$ & .20790 & $-1.187-$ & 49 & .241 \\
\hline Pair 3 ho - $m$ & .30435 & 2.04254 & .30116 & $-.30221-$ & .91091 & 1.011 & 45 & .318 \\
\hline
\end{tabular}

\begin{tabular}{|c|c|c|c|c|c|}
\hline \multicolumn{7}{|c|}{ ANOVA } \\
\hline & Sum of Squares & Df & Mean Square & F & Sig. \\
\hline Between Groups & 2.527 & 2 & 1.263 & .657 & .520 \\
Within Groups & 280.695 & 146 & 1.923 & & \\
Total & 283.221 & 148 & & & \\
\hline
\end{tabular}

\begin{tabular}{|c|c|c|c|}
\hline \multicolumn{3}{|c|}{ Duncan test } \\
\hline & VAR00003 & \multirow{2}{*}{$\mathrm{N}$} & Subset for alpha $=0.05$ \\
\cline { 3 - 4 } & & & 1 \\
\hline & $\mathrm{T}$ & 50 & 6.2200 \\
Duncan $^{\mathrm{a}, \mathrm{b}}$ & $\mathrm{M}$ & 46 & 6.2609 \\
& Ho & 53 & 6.5094 \\
& Sig. & & .332 \\
\hline
\end{tabular}

Means for groups in homogeneous subsets are displayed.

a. Uses Harmonic Mean Sample Size $=49.499$.

b. The group sizes are unequal. The harmonic mean of the group sizes is used. Type I error levels are not guaranteed. 
Table -5. Statistical analysis for assessment score regarding sufficient gain of communication skills and ability to work in teams

\begin{tabular}{|c|c|c|c|c|c|c|c|c|}
\hline \multicolumn{9}{|c|}{ Paired Samples Test } \\
\hline & \multicolumn{5}{|c|}{ Paired Differences } & \multirow{3}{*}{$\mathrm{t}$} & \multirow{3}{*}{ df } & \multirow{3}{*}{$\begin{array}{l}\text { Sig. (2- } \\
\text { tailed) }\end{array}$} \\
\hline & \multirow[t]{2}{*}{ Mean } & \multirow{2}{*}{$\begin{array}{l}\text { Std. } \\
\text { Deviation }\end{array}$} & \multirow{2}{*}{$\begin{array}{l}\text { Std. Error } \\
\text { Mean }\end{array}$} & \multicolumn{2}{|c|}{$\begin{array}{c}95 \% \text { Confidence Interval } \\
\text { of the Difference }\end{array}$} & & & \\
\hline & & & & Lower & Upper & & & \\
\hline Pair $1 \mathrm{~m}-\mathrm{t}$ & $-.24444-$ & 1.77297 & .26430 & $-.77710-$ & .28822 & $-.925-$ & 44 & .360 \\
\hline Pair $2 \mathrm{t}-$ ho & .26531 & 1.85714 & .26531 & $-.26813-$ & .79874 & 1.000 & 48 & .322 \\
\hline Pair 3 ho $-\mathrm{m}$ & .13043 & 2.01780 & .29751 & $-.46878-$ & .72965 & .438 & 45 & .663 \\
\hline
\end{tabular}

\begin{tabular}{|c|c|c|c|c|c|}
\hline \multicolumn{7}{|c|}{ ANOVA } \\
\hline & Sum of Squares & Df & Mean Square & F & Sig. \\
\hline Between Groups & 2.154 & 2 & 1.077 & .605 & .547 \\
Within Groups & 258.029 & 145 & 1.780 & & \\
Total & 260.182 & 147 & & & \\
\hline
\end{tabular}

\begin{tabular}{|c|c|c|c|}
\hline \multicolumn{3}{|c|}{ Duncan test } \\
\hline \multirow{2}{*}{ VAR00003 } & \multirow{2}{*}{ N } & 1 \\
\cline { 3 - 4 } & M & 46 & 6.3043 \\
Duncan $^{\mathrm{a}, \mathrm{b}}$ & $\mathrm{Ho}$ & 53 & 6.3774 \\
& $\mathrm{~T}$ & 49 & 6.5918 \\
& Sig. & & .318 \\
\hline
\end{tabular}

Means for groups in homogeneous subsets are displayed.

a. Uses Harmonic Mean Sample Size $=49.168$.

b. The group sizes are unequal. The harmonic mean of the group sizes is used. Type I error levels are not guaranteed.

Table -6. Statistical analysis for assessment results regarding whether the graduate gain the confidence of patients and other health workers

\begin{tabular}{|c|c|c|c|c|c|c|c|c|}
\hline \multicolumn{9}{|c|}{ Paired Samples Test } \\
\hline & \multicolumn{5}{|c|}{ Paired Differences } & \multirow{3}{*}{$\mathrm{T}$} & \multirow{3}{*}{ df } & \multirow{3}{*}{$\begin{array}{l}\text { Sig. }(2 \\
\text { tailed) }\end{array}$} \\
\hline & \multirow{2}{*}{ Mean } & \multirow{2}{*}{$\begin{array}{c}\text { Std. } \\
\text { Deviation }\end{array}$} & \multirow{2}{*}{$\begin{array}{l}\text { Std. Error } \\
\text { Mean }\end{array}$} & \multicolumn{2}{|c|}{$\begin{array}{l}95 \% \text { Confidence Interval } \\
\text { of the Difference }\end{array}$} & & & \\
\hline & & & & Lower & Upper & & & \\
\hline Pair $1 \mathrm{~m}-\mathrm{t}$ & 1.39130 & 10.75273 & 1.58540 & $-1.80186-$ & 4.58447 & .878 & 45 & .385 \\
\hline Pair $2 \mathrm{t}-$ ho & $-.06000-$ & 1.93158 & .27317 & $-.60895-$ & .48895 & $-.220-$ & 49 & .827 \\
\hline Pair 3 ho $-\mathrm{m}$ & $-1.17391-$ & 10.37798 & 1.53015 & -4.25579 & 1.90797 & $-.767-$ & 45 & .447 \\
\hline
\end{tabular}




\begin{tabular}{|c|c|c|c|c|c|}
\hline \multicolumn{7}{|c|}{ ANOVA } \\
\hline & $\begin{array}{c}\text { Sum of } \\
\text { Squares }\end{array}$ & Df & $\begin{array}{c}\text { Mean } \\
\text { Square }\end{array}$ & F & Sig. \\
\hline $\begin{array}{c}\text { Between } \\
\text { Groups } \\
\text { Within } \\
\text { Groups } \\
\text { Total }\end{array}$ & 55.669 & 2 & 27.834 & .778 & .461 \\
5220.613 & 146 & 35.758 & & \\
\hline
\end{tabular}

\begin{tabular}{|c|c|c|c|}
\hline \multicolumn{3}{|c|}{ Duncan test } \\
\hline \multicolumn{2}{|c|}{ VAR00003 } & $\mathrm{N}$ & $\begin{array}{c}\text { Subset for } \\
\text { alpha }=0.05\end{array}$ \\
\cline { 4 - 4 } & & & 1 \\
\hline & $\mathrm{T}$ & 50 & 6.6800 \\
Duncan $^{\mathrm{a}, \mathrm{b}}$ & $\mathrm{Ho}$ & 53 & 6.7170 \\
& $\mathrm{M}$ & 46 & 8.0217 \\
& Sig. & & .297 \\
\hline
\end{tabular}

Means for groups in homogeneous subsets are displayed.

a. Uses Harmonic Mean Sample Size $=49.499$.

b. The group sizes are unequal. The harmonic mean of the group sizes is used. Type I error levels are not guaranteed.

\section{DISCUSSION}

The assessment results revealed a relatively low mean scores for the gained knowledge regarding surgical capabilities of newly graduating doctors and their ability to practice team work and to communicate properly with health services consumers. Such result can be explained through the fact that Iraqi colleges of medicine are concentrating more on students' attendance and less on updating the curriculum which is outdated. Each medical college has its own curriculum, and there are no guidelines that apply to all medical schools. Learning is still traditional, and characterized by a teacher-centered approach. This method centers on the teacher who is controlling the course content and the methods of presentation i.e. focusing on teaching rather than learning 5,6 . The modern style of medical education has at yet been introduced: the one which depends on a student-centered approach in which the students are encouraged to take greater responsibility for learning decisions and to question what and how they learn, while they are supervised by a mentor ${ }^{5,7}$.

There is a worldwide continuous discussions and efforts to improve the clinical training of medical schools students including surgical training in last two decades ${ }^{1}$. Medical students across the United
Kingdom report a diminished surgical training in hospitals and a lower satisfaction with surgical teaching ${ }^{8}$. Most students expressed uncertainty in clinical surgical skills ${ }^{1}$. American medical students finding their clinical training programs inadequate ${ }^{9}$.

From other point of view, the assessment results revealed a statistically significant unacceptable low mean scores for the gained surgical skills of graduates. As the graduate start to work among surgical wards and casualty units, they feel an actual deficit on their clinical surgical skills and inability to do properly all essential skills and some lifesaving surgical maneuvers or procedures. Most students expressed uncertainty in clinical skills , such as performing a surgical suture or applying gypsum/bandage. Students feel unprepared for clinical every day work due to lacking training of basic practical skill within the frame work of their training ${ }^{1}$

Surgical training may fail to produce competent graduates ${ }^{2}$. Medical students surgical training differs in the various countries. ${ }^{1,3}$. In developing countries, the surgical training of undergraduate student shows significantly lower level in comparison with developed countries ${ }^{3}$. The surgical skills , technical knowledge, basic surgical knowledge, and surgical judgment among surgical trainees can be assessed ${ }^{10}$.

There is marked deterioration in medical services and medical teaching in Iraq in the last three decades caused by many factors. The 2003 USA and coalition invasion of Iraq accelerated a steady deterioration in medical services and medical training and graduates. Iraqi political problems had a marked effects on health fields. .The 2014 invasion of Iraq by ISIS (Islamic State of Iraq and Syria) made the condition worse ${ }^{5}$. The level of surgical skill in graduates of our college was significantly low, this reported by resident doctors work in surgical wards, and it is lower than that reported by Westermann et al. The knowledge and clinical skills deficiency had been observed in the students of our college. ${ }^{5,6,11,12}$

Medical colleges should revise, innovate and evaluate training programs carried out at their different departments to produce competent graduates meet the needs of their local community with changes in these programs including quantity, quality, efficiency, and mode of delivery. Outpatient and emergency department should be created in site of training, this can be applied when there is limited resources like our situation.. The network and social media can be used to improve the training and in follow-up of students . The network, social media, skill laboratories, intensive courses and computer facilities can improve the surgical training and this proved by many studies ${ }^{2,7,13-15}$. Medical students should 
gain sufficient essential knowledge, clinical skills and good communication skills to deal with patients and other health workers ${ }^{6,16}$.

This study is the first trial to evaluate surgical training in our region. We depended on selfevaluation of surgical training by final year medical school students, and recently graduated resident doctors work in surgical wards, this method usually used in clinical training evaluation even this questionnaire is not validated ${ }^{1,3}$. In our study experts surgeons involved in medical teaching share in study, they represent the stakeholders ${ }^{14}$.

\section{CONCLUSION \& RECOMMENDATION}

The study can conclude that there is relatively low level of surgical skill gaining among Mosul college graduates with low level in knowledge gaining, ability to communicate with patients and work as a team, provide safe doctor in work, gaining the confidence of patients and other health workers. There is a need for more clinical training, improvement and development of clinical training. The shortage of tertiary hospital can be compensated by using out patients, rural hospital or emergency department for teaching and creation of more outpatients and emergency room for teaching and to serve the community

\section{REFERENCES}

1.Westermann L, Zisimidou B, Simons M, Rene Zellweger R, Baschera D. Self-evaluation of present clinical skills by medical students in the years 3 to 6 - a pilot study in four European countries. GMS J Med Educ. 2018; 35(3): Doc36. Published online 2018 Aug 15. doi: 10.3205/zma001182.

2.Birch DW , Brian Mavis B. A needs assessment study of undergraduate surgical education. Can J Surg. 2006 Oct; 49(5): 335-340.

3.Scott A J, Drevin G, Pavlović L, Nilsson M, Krige J E J, Jonas E. Medical Student And Faculty Perceptions Of Undergraduate Surgical Training In The South African And Swedish Tertiary Institutions: A Cross-Sectional Survey. Adv Med Educ Pract. 2019; 10: 855-866.

4.Bennett SR, Morris SR, Mirza S. Medical Students Teaching Medical Students Surgical Skills: The Benefits of Peer-Assisted Learning. J Surg Educ. 2018 Nov;75(6):1471-1474.

5.Al-Shamsi M . Medical education in Iraq: issues and challenges. Int J Med Educ. 2017; 8: 88-90.

6. Al-Dabbagh S A, Al-Taee W G. Evaluation of a task-based community oriented teaching model in family medicine for undergraduate medical students in Iraq. BMC Medical Education. 2005; 5: 31 - 39.
7.Bruening $\mathrm{M} \mathrm{H}$, Maddern $\mathrm{G} J$. Surgical Undergraduate Education in Rural Australia. Arch Surg. 2002;137(7):794-798.

8. Hakim M A, Dominguez E D, Priest S, Lee K S, Mlardanpour A, Tandle $S$. Surgical Skills Workshops Should $\mathrm{Be}$ a Part of the United Kingdom Undergraduate Medical Curriculum. Cureus. 2019 May;11(5): e4642.

9. Tardif A G, Laporte G B, Khwaja K, Ntakiyiruta G, Kyamanywa P, Razek T, Deckelbaum et al. Enhancing medical students' education and careers in global surgery. Can J Surg. 2014 Aug; 57(4): 224-225.

10. Balayla J, Bergman S, Ghitulescu G, Feldman L S, Fraser S A. Can J Surg. Knowing the operative game plan: a novel tool for the assessment of surgical procedural knowledge. 2012 Aug; 55(4 Suppl 2): S158-S162.

11. Nordquist J, Sundberg K, Johansson L, Sandelin K, Nordenström J. Case-based learning in surgery: lessons learned. World J Surg. 2012 May;36(5):945-55.

12. Lafta R, Al-Ani W, Dhiaa S, Cherewick M, Hagopian A , Burnham G. Perceptions, experiences and expectations of Iraqi medical students. BMC Medical Education, 2018; 18: 53 -60 .

13. Alexander EK. Perspective: moving students beyond an organ-based approach when teaching medical interviewing and physical examination skills. Acad Med. 2008;83(10):906-909.

14. Li J Z, Chan S C Y, Au M, Hoogenes J, Chan T, Li K, Reid S. Review of a medical student-run surgery lecture series and skills lab curriculum. Can J Surg. 2014 Jun; 57(3): 152-154.

15. Härtl $A$, Berberat $P$, Fischer $M R$, Forst $H$, Grützner S, Händl T et al. Development of the competency-based medical curriculum for the new Augsburg University Medical School. J Med Educ. 2017; 34(2): Published online 2017 May 15. doi: $10.3205 / z m a 001098$.

16. Gómez S S , Ostos E M C, Solano J M M , Salado $T F H$. An electronic portfolio for quantitative assessment of surgical skills in undergraduate medical education. Medical Education 2013; 13:65. https://doi.org/10.1186/1472-6920-13-65. 